\title{
Radium-based estimates of cesium isotope transport and total direct ocean discharges from the Fukushima Nuclear Power Plant accident
}

\author{
M. A. Charette ${ }^{1}$, C. F. Breier ${ }^{1}$, P. B. Henderson ${ }^{1}$, S. M. Pike ${ }^{1}$, I. I. Rypina ${ }^{2}$, S. R. Jayne ${ }^{2}$, and K. O. Buesseler ${ }^{1}$ \\ ${ }^{1}$ Department of Marine Chemistry and Geochemistry, Woods Hole Oceanographic Institution, Woods Hole, MA 02543, USA \\ ${ }^{2}$ Department of Physical Oceanography, Woods Hole Oceanographic Institution, Woods Hole, MA 02543, USA
}

Correspondence to: M. A. Charette (mcharette@whoi.edu)

Received: 30 October 2012 - Published in Biogeosciences Discuss.: 15 November 2012

Revised: 1 March 2013 - Accepted: 7 March 2013 - Published: 28 March 2013

\begin{abstract}
Radium has four naturally occurring isotopes that have proven useful in constraining water mass source, age, and mixing rates in the coastal and open ocean. In this study, we used radium isotopes to determine the fate and flux of runoff-derived cesium from the Fukushima Dai-ichi Nuclear Power Plant (FNPP). During a June 2011 cruise, the highest cesium (Cs) concentrations were found along the eastern shelf of northern Japan, from Fukushima south, to the edge of the Kuroshio Current, and in an eddy $\sim 130 \mathrm{~km}$ from the FNPP site. Locations with the highest cesium also had some of the highest radium activities, suggesting much of the direct ocean discharges of Cs remained in the coastal zone 23 months after the accident. We used a short-lived Ra isotope $\left({ }^{223} \mathrm{Ra}, t_{1 / 2}=11.4 \mathrm{~d}\right)$ to derive an average water mass age $\left(T_{\mathrm{r}}\right)$ in the coastal zone of 32 days. To ground-truth the $\mathrm{Ra}$ age model, we conducted a direct, station-by-station comparison of water mass ages with a numerical oceanographic model and found them to be in excellent agreement (model avg. $T_{\mathrm{r}}=27$ days). From these independent $T_{\mathrm{r}}$ values and the inventory of Cs within the water column at the time of our cruise, we were able to calculate an offshore ${ }^{134} \mathrm{Cs}$ flux of $3.9-4.6 \times 10^{13} \mathrm{~Bq} \mathrm{~d}^{-1}$. Radium-228 $\left(t_{1 / 2}=5.75 \mathrm{yr}\right)$ was used to derive a vertical eddy diffusivity $\left(K_{z}\right)$ of $0.7 \mathrm{~m}^{2} \mathrm{~d}^{-1}$ $\left(0.1 \mathrm{~cm}^{2} \mathrm{~s}^{-1}\right)$; from this $K_{z}$ and ${ }^{134} \mathrm{Cs}$ inventory, we estimated a ${ }^{134} \mathrm{Cs}$ flux across the pycnocline of $1.8 \times 10^{4} \mathrm{~Bq} \mathrm{~d}^{-1}$ for the same time period. On average, our results show that horizontal mixing loss of $\mathrm{Cs}$ from the coastal zone was $\sim 10^{9}$ greater than vertical exchange below the surface mixed layer. Finally, a mixing/dilution model that utilized our Ra-based and oceanographic model water mass ages produced a direct ocean discharge of ${ }^{134} \mathrm{Cs}$ from the FNPP of $11-16 \mathrm{PBq}$ at the time of the peak release in early April 2011. Our results
\end{abstract}

can be used to calculate discharge of other water-soluble radionuclides that were released to the ocean directly from the Fukushima NPP.

\section{Introduction}

On 11 March 2011, an offshore magnitude 9.0 earthquake and resulting tsunami led to several hydrogen explosions and reactor meltdowns at the Fukushima Dai-ichi Nuclear Power Plant (FNPP) in Japan. The accident resulted in a large-scale release of radioactivity to the environment through atmospheric fallout over land and sea, as well as direct discharge to the ocean from water used to cool the reactors (Buesseler et al., 2011; Chino et al., 2011).

Arguably, the largest ocean-related impact was from the release of two cesium isotopes $\left({ }^{137} \mathrm{Cs}, t_{1 / 2}=30.2 \mathrm{yr} ;{ }^{134} \mathrm{Cs}\right.$, $t_{1 / 2}=2.06 \mathrm{yr}$ ), relatively volatile fission products that are highly soluble in seawater (oceanic residence time of stable Cs is $\sim 330000 \mathrm{yr}$; Broecker and Peng, 1982). The release ratio of ${ }^{137} \mathrm{Cs}:{ }^{134} \mathrm{Cs}$, an indicator of the degree of burn up of the fuel used and stored on site, was 1.0 (in units of activity). Concentrations in the ocean peaked on 6 April (activities of up to $60000000 \mathrm{~Bq} \mathrm{~m}^{-3}$ ), when direct discharge was highest, and as of this writing continue to make the Fukushima event the largest accidental release of ${ }^{137} \mathrm{Cs}$ to the ocean (Buesseler et al., 2012).

In June of 2011, an international group of scientists set out to measure the oceanic distribution of radionuclides released from the FNPP along the coast and offshore of Japan (Buesseler et al., 2012). In addition to the measurement of radionuclides derived from the NPP, radium isotopes 
were measured to trace the pathway of the cesium derived from direct ocean discharges. In marine environments, radium isotopes are produced from the decay of thorium isotopes, which are abundant in sediments along the coastline (Moore, 2000). Unlike thorium, radium is soluble in seawater, making leakage from continental margin sediments a continuous source of radium isotopes to the ocean. Hence, with four naturally occurring isotopes with wide ranging half-lives $\left({ }^{224} \mathrm{Ra}=3.66 \mathrm{~d},{ }^{223} \mathrm{Ra}=11.4 \mathrm{~d},{ }^{228} \mathrm{Ra}=5.75 \mathrm{yr}\right.$, ${ }^{226} \mathrm{Ra}=1600 \mathrm{yr}$ ), $\mathrm{Ra}$ isotopes have been applied to the study of ocean mixing processes (e.g. Moore, 2000; Dulaiova et al., 2009) and land-ocean fluxes of dissolved trace elements and isotopes (e.g. Krest et al., 2000; Charette et al., 2007).

Our study had three main objectives for the combined Cs and Ra isotope dataset from the June 2011 cruise. First, we sought to determine the provenance of the surface water (coastal vs. open ocean) associated with FNPP-derived ${ }^{137} \mathrm{Cs}$ and ${ }^{134} \mathrm{Cs}$. We accomplished this using ${ }^{228} \mathrm{Ra} /{ }^{226} \mathrm{Ra}$ ratios as well as water mass age estimates derived from short-lived $\mathrm{Ra}$ isotopes. Second, we wanted to derive the offshore and vertical (cross-thermocline) fluxes of Cs isotopes. Lastly, we attempted to derive the inventory of ${ }^{137} \mathrm{Cs}$ and ${ }^{134} \mathrm{Cs}$ from direct ocean discharge, which peaked in early April 2011.

\section{Methods}

Seawater samples for radium analysis were collected in June 2011 aboard the R/V Ka'imikai-o-Kanaloa from 34 stations along the coast and offshore of Japan (Fig. 1a). Surface radium samples were collected by pre-concentrating $\mathrm{Ra}$ from $1 \mu \mathrm{m}$ prefiltered (Hytrex) seawater onto either $\mathrm{MnO}_{2}$ coated acrylic fiber and/or $\mathrm{MnO}_{2}$ impregnated acrylic cartridges. Samples processed with $\mathrm{MnO}_{2}$ acrylic fibers were collected with a surface pump from a water depth of $0.5 \mathrm{~m}$ into plastic barrels $(200-300 \mathrm{~L})$, then passed through the fibers at $<1 \mathrm{~L} \mathrm{~min}^{-1}$ (Moore, 2008) (Table 1). $\mathrm{MnO}_{2}$ impregnated acrylic cartridge surface samples were collected with paired cartridges located downstream of the prefilter and two Cs cartridges (Buesseler et al., 1990) (Table 2). Vertical profile samples (1000-1500 L) were collected onto $\mathrm{MnO}_{2}$ impregnated acrylic cartridges adapted to fit onto a McLane large volume in situ pumping system (Henderson et al., 2012) (Table 2). While the Mn fiber method scavenges Ra quantitatively, the Mn cartridge method does not. Hence, while absolute $\mathrm{Ra}$ values are available for the former, only $\mathrm{Ra}$ isotopic ratios are available for the latter.

While onboard the vessel, $\mathrm{MnO}_{2}$ fiber and cartridge samples were rinsed with deionized water to remove salts and dried to dampness. ${ }^{223} \mathrm{Ra}$ and ${ }^{224} \mathrm{Ra}$ activities were measured by alpha decay on a delayed coincidence counter ( $\mathrm{RaDeCC}$; Moore and Arnold, 1996) within 2 days of collection. Samples were alpha counted a second and third time (at 4 weeks and $>2$ months) to correct for radium supported in the water column from parent nuclide decay $\left({ }^{224} \mathrm{Ra}\right.$ from ${ }^{228} \mathrm{Th}$ and

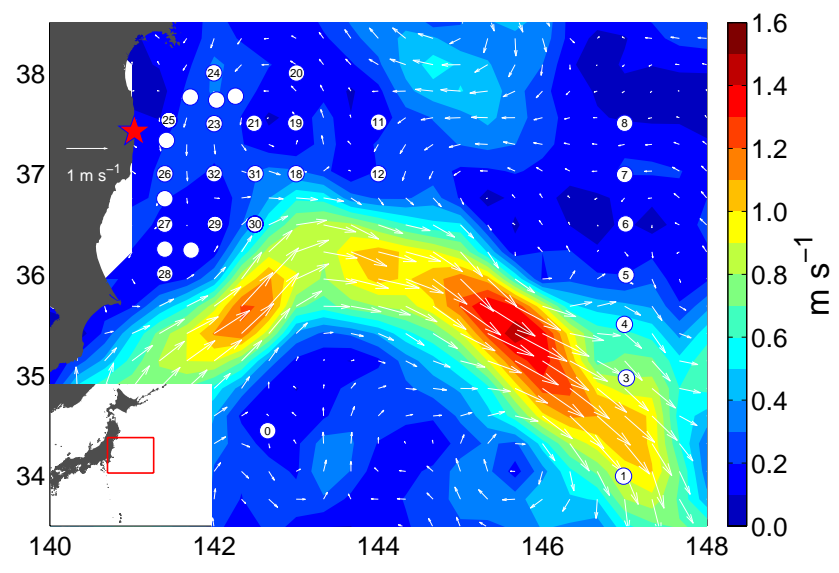

Fig. 1. Station map for the June 2011 cruise, including the location of the Fukushima NPP (red star). The unlabeled station symbols are the location of "half stations" (Table 1). The half stations immediately follow the whole number stations along the cruise track (e.g. station 28.5 falls between stations 28 and 29). Color contours represent the current speed in $\mathrm{m} \mathrm{s}^{-1}$ derived from AVISO satellite altimetry data.

${ }^{223} \mathrm{Ra}$ from ${ }^{227} \mathrm{Ac}$ ). Hence, values reported here are radium in excess of their parent isotopes. Samples were then prepared for counting of long-lived isotopes via gamma spectroscopy. Briefly, samples were ashed at $820^{\circ} \mathrm{C}$ for $16 \mathrm{~h}$ in the case of fiber (Charette et al., 2001) and $48 \mathrm{~h}$ for cartridges (Henderson et al., 2012). The ash was homogenized, packed in a polystyrene vial, and sealed for 3 weeks to allow ingrowth of ${ }^{214} \mathrm{~Pb}$ from ${ }^{226} \mathrm{Ra} .{ }^{226} \mathrm{Ra}$ and ${ }^{228} \mathrm{Ra}$ were measured on calibrated germanium well detectors at 352 and $911 \mathrm{KeV}$. Uncertainties for ${ }^{224} \mathrm{Ra}$ and ${ }^{223} \mathrm{Ra}$ were in the range of $10-50 \%$ while average uncertainties ${ }^{228} \mathrm{Ra}$ and ${ }^{226} \mathrm{Ra}$ were $10.8 \%$ and $2.6 \%$, respectively. Much of the ${ }^{224} \mathrm{Ra}$ data was below the detection limit of our method due to its relatively short halflife and the long water residence times within our study domain.

Cesium samples were collected from the surface with a deck pump (as above) and at depth from Niskin bottles. Cesium was extracted from seawater by pumping samples through a column containing ammonium phosphomolybdate resin. The resin containing Cs was loaded into a counting vial and Cs activities were measured directly on a germanium well detector at 605,661 and $795 \mathrm{KeV}$, for ${ }^{134} \mathrm{Cs}$, ${ }^{137} \mathrm{Cs}$, and ${ }^{134} \mathrm{Cs}$, respectively (Pike et al., 2012). Further details on the Cs results can be found in Buesseler et al. (2012). All Ra and Cs data are available online at the Biological and Chemical Oceanography Data Management Office (BCO-DMO; http://osprey.bcodmo.org/project. $\mathrm{cfm}$ ?flag=viewd\&id=186\&sortby=project $)$. 
Table 1. Radium and $\mathrm{Cs}$ isotopes for stations were $\mathrm{MnO}_{2}$ acrylic fibers were used.

\begin{tabular}{|c|c|c|c|c|c|c|c|c|c|c|c|c|c|c|c|c|c|c|c|}
\hline $\begin{array}{r}\text { Station } \\
\text { ID }\end{array}$ & $\begin{array}{r}\text { Depth } \\
(\mathrm{m})\end{array}$ & $\begin{array}{l}\text { Lat. } \\
\left({ }^{\circ} \mathrm{N}\right)\end{array}$ & $\begin{array}{l}\text { Long. } \\
\left({ }^{\circ} \mathrm{E}\right)\end{array}$ & Salinity & ${ }^{137} \mathrm{Cs}$ & $\begin{array}{r}\text { error } \\
\text { (Bq }\end{array}$ & ${ }^{134} \mathrm{Cs}$ & error & ${ }^{134} \mathrm{Cs} /{ }^{137} \mathrm{Cs}$ & ${ }^{226} \mathrm{Ra}$ & $\begin{array}{l}\text { error } \\
\text { (dpm } 1\end{array}$ & $\begin{array}{l}{ }^{228} \mathrm{Ra} \\
\left.0 \mathrm{~L}^{-1}\right)\end{array}$ & error & ${ }^{228} \mathrm{Ra} /{ }^{226} \mathrm{Ra}$ & $\begin{array}{l}{ }^{223} \mathrm{Ra} \\
\text { (dpm } 10\end{array}$ & $\begin{array}{r}\text { error } \\
\left.0 \mathrm{~L}^{-1}\right)\end{array}$ & ${ }^{223} \mathrm{Ra} /{ }^{228} \mathrm{Ra}$ & $\begin{array}{r}{ }^{223} \mathrm{Ra} /{ }^{228} \mathrm{Ra} \\
\text { Age (d) }\end{array}$ & $\begin{array}{r}\text { PO Model } \\
\text { Age (d) }\end{array}$ \\
\hline 19 & 0.5 & 37.505 & 142.995 & 34.138 & 236 & 5 & 244 & 4 & 1.0 & 9.77 & 0.20 & 2.87 & 0.38 & 0.29 & 0.031 & 0.015 & $1.08 \mathrm{E}-02$ & 22 & 48.7 \\
\hline 21 & 0.5 & 37.501 & 142.486 & 34.168 & 211 & 6 & 223 & 5 & 0.9 & 7.86 & 0.17 & 2.69 & 0.31 & 0.34 & & & & & 59.8 \\
\hline 23.5 & 0.5 & 37.733 & 142.026 & 33.891 & 475 & 12 & 476 & 9 & 1.0 & 6.26 & 0.13 & 2.34 & 0.22 & 0.37 & 0.002 & 0.003 & $8.36 \mathrm{E}-04$ & & 44.2 \\
\hline 24.5 & 0.5 & 37.757 & 141.708 & 33.886 & 380 & 11 & 403 & 9 & 0.9 & 8.81 & 0.28 & 4.19 & 0.47 & 0.48 & 0.163 & 0.030 & 3.90E-02 & 2.0 & 15.8 \\
\hline 25 & 0.5 & 37.531 & 141.446 & 33.755 & 582 & 14 & 595 & 10 & 1.0 & 9.06 & 0.17 & 3.40 & 0.30 & 0.38 & 0.039 & 0.017 & $1.15 \mathrm{E}-02$ & 22 & 11.1 \\
\hline 25.5 & 0.5 & 37.333 & 141.424 & 33.992 & 749 & 19 & 773 & 16 & 1.0 & 5.74 & 0.13 & 4.66 & 0.29 & 0.81 & 0.074 & 0.021 & 1.60E-02 & 17 & 5.4 \\
\hline 26.5 & 0.5 & 36.745 & 141.404 & 33.678 & 537 & 14 & 556 & 11 & 1.0 & 8.39 & 0.28 & 2.28 & 0.45 & 0.27 & 0.007 & 0.006 & $2.89 \mathrm{E}-03$ & 43 & 4.5 \\
\hline 28.5 & 0.5 & 36.244 & 141.717 & 33.687 & 1622 & 39 & 1705 & 31 & 1.0 & 8.66 & 0.27 & 4.71 & 0.49 & 0.54 & 0.145 & 0.025 & 3.07E-02 & 6.2 & 23.2 \\
\hline 29 & 0.5 & 36.498 & 142.010 & 33.282 & 3477 & 70 & 3565 & 37 & 1.0 & 9.24 & 0.28 & 6.89 & 0.56 & 0.75 & 0.202 & 0.036 & 2.94E-02 & 7.5 & 16.2 \\
\hline 30 & 0.5 & 36.496 & 142.495 & 33.965 & 720 & 17 & 738 & 13 & 1.0 & 6.95 & 0.18 & 1.96 & 0.29 & 0.28 & 0.029 & 0.014 & $1.50 \mathrm{E}-02$ & 15 & 21.4 \\
\hline 32 & 0.5 & 36.998 & 142.001 & 34.112 & 327 & 8 & 332 & 6 & 1.0 & 8.53 & 0.15 & 3.46 & 0.28 & 0.41 & 0.016 & 0.009 & $4.71 \mathrm{E}-03$ & 36 & 36.7 \\
\hline
\end{tabular}

Table 2. Radium and $\mathrm{Cs}$ isotopes for stations were $\mathrm{MnO}_{2}$ acrylic cartridges were used.

\begin{tabular}{|c|c|c|c|c|c|c|c|c|c|c|c|c|c|}
\hline Station ID & Depth (m) & Lat. $\left({ }^{\circ} \mathrm{N}\right)$ & Long. $\left({ }^{\circ} \mathrm{E}\right)$ & Salinity & ${ }^{137} \mathrm{Cs}$ & $\begin{array}{l}\text { error } \\
\qquad(\mathrm{Bqr}\end{array}$ & ${ }_{\left.n^{-3}\right)}^{134} \mathrm{Cs}$ & error & ${ }^{134} \mathrm{Cs} /{ }^{137} \mathrm{Cs}$ & ${ }^{228} \mathrm{Ra} /{ }^{226} \mathrm{Ra}$ & ${ }^{223} \mathrm{Ra} /{ }^{228} \mathrm{Ra}$ & $\begin{array}{r}{ }^{223} \mathrm{Ra} /{ }^{228} \mathrm{Ra} \\
\text { Age }(\mathrm{d})\end{array}$ & $\begin{array}{r}\text { PO Model } \\
\text { Age (d) }\end{array}$ \\
\hline 0 & 0.5 & 34.445 & 142.653 & 34.713 & 6.9 & 0.4 & 5.9 & 0.5 & 1.2 & 0.29 & & & \\
\hline 1 & 0.5 & 33.995 & 146.987 & 34.715 & 3.3 & 0.2 & 2.4 & 0.3 & 1.4 & 0.20 & & & \\
\hline 3 & 0.5 & 34.971 & 147.022 & 34.706 & & & & & & & & & \\
\hline 3 & 20 & 34.971 & 147.022 & 34.706 & 1.7 & 0.3 & bd & 0.0 & & 0.29 & & & \\
\hline 3 & 50 & 34.971 & 147.022 & 34.713 & 1.8 & 0.2 & bd & 0.0 & & 1.07 & & & \\
\hline 3 & 200 & 34.971 & 147.022 & 34.657 & 2.5 & 0.2 & bd & 0.0 & & & & & \\
\hline 4 & 0.5 & 35.502 & 146.999 & 34.335 & 317 & 9.8 & 315 & 8.6 & 1.0 & 0.01 & & & \\
\hline 5 & 0.5 & 35.993 & 147.016 & 34.541 & 25.2 & 0.7 & 23.3 & 0.7 & 1.1 & 0.60 & & & \\
\hline 6 & 0.5 & 36.500 & 147.011 & 34.576 & & & & & & 0.25 & & & \\
\hline 7 & 0.5 & 36.991 & 147.000 & 34.173 & 202 & 5.3 & 203 & 4.2 & 1.0 & 0.26 & $1.24 \mathrm{E}-02$ & 23 & \\
\hline 8 & 0.5 & 37.502 & 147.000 & 34.312 & 336 & 8.4 & 334 & 6.6 & 1.0 & 0.28 & & & \\
\hline 11 & 0.5 & 37.511 & 144.003 & 33.909 & 100 & 3.1 & 104 & 2.9 & 1.0 & 0.36 & $2.27 \mathrm{E}-03$ & & \\
\hline 12 & 0.5 & 36.996 & 144.004 & 34.350 & 89.1 & 2.0 & 86 & 1.4 & 1.0 & 0.40 & $2.02 \mathrm{E}-02$ & 15 & \\
\hline 14 & 0.5 & 35.996 & 144.006 & 34.733 & 2.3 & 0.4 & 1.1 & 0.6 & 2.1 & & $5.04 \mathrm{E}-04$ & & \\
\hline 18 & 0.5 & 36.999 & 143.000 & 34.285 & 204 & 4.7 & 204 & 3.3 & 1.0 & 0.15 & $3.05 \mathrm{E}-02$ & 8.1 & \\
\hline 19 & 0.5 & 37.505 & 142.995 & 33.844 & 236 & 5.4 & 244 & 3.9 & 1.0 & 0.21 & $2.70 \mathrm{E}-02$ & & 50.9 \\
\hline 19 & 10 & 37.505 & 142.995 & no data & & & & & & & 4.43E-03 & & \\
\hline 19 & 20 & 37.505 & 142.995 & 34.228 & 289 & 6.4 & 287 & 4.2 & 1.0 & 0.32 & $1.43 \mathrm{E}-02$ & & \\
\hline 19 & 50 & 37.505 & 142.995 & 33.986 & 190 & 5.6 & 186 & 5.0 & 1.0 & 0.34 & & & \\
\hline 19 & 200 & 37.505 & 142.995 & 33.803 & 3.0 & 0.3 & 1.8 & 0.3 & 1.7 & 0.18 & $3.56 \mathrm{E}-03$ & & \\
\hline 20 & 0.5 & 38.000 & 143.003 & 34.436 & 22.2 & 0.7 & 21.9 & 0.6 & 1.0 & 0.39 & $2.87 \mathrm{E}-03$ & 47 & \\
\hline 21 & 0.5 & 37.501 & 142.486 & 33.826 & 211 & 6.0 & 223 & 5.2 & 0.9 & 0.46 & $1.52 \mathrm{E}-03$ & 53 & 41.8 \\
\hline 21 & 20 & 37.503 & 142.491 & 34.241 & 252 & 5.6 & 247 & 3.7 & 1.0 & 0.47 & $3.60 \mathrm{E}-03$ & & \\
\hline 21 & 50 & 37.503 & 142.491 & 33.977 & 129 & 4.2 & 126 & 4.0 & 1.0 & 0.24 & 4.42E-03 & & \\
\hline 21 & 100 & 37.503 & 142.491 & 33.686 & 51.1 & 1.5 & 46.9 & 1.3 & 1.1 & 0.08 & $4.78 \mathrm{E}-03$ & & \\
\hline 21 & 200 & 37.503 & 142.491 & 33.697 & 2.0 & 0.1 & bd & 0.0 & & 0.15 & $5.43 \mathrm{E}-03$ & & \\
\hline 23 & 0.5 & 37.496 & 142.000 & 33.963 & 822 & 17.6 & 834 & 10.9 & 1.0 & 0.31 & $1.57 \mathrm{E}-03$ & 51 & 34.8 \\
\hline 23 & 10 & 37.481 & 142.005 & 34.016 & 920 & 19.2 & 896 & 11.0 & 1.0 & 0.40 & & & \\
\hline 23 & 20 & 37.481 & 142.005 & 34.091 & 993 & 22.8 & 972 & 15.7 & 1.0 & 0.40 & 8.59E-04 & & \\
\hline 23 & 50 & 37.481 & 142.005 & 34.054 & 992 & 20.0 & 1000 & 10.5 & 1.0 & 0.39 & 7.23E-03 & & \\
\hline 23 & 100 & 37.481 & 142.005 & 33.726 & 107 & 2.2 & 107 & 1.2 & 1.0 & 0.46 & $1.17 \mathrm{E}-03$ & & \\
\hline 24 & 0.5 & 38.001 & 141.997 & 34.519 & 43.2 & 1.4 & 42.2 & 1.3 & 1.0 & 0.23 & $3.05 \mathrm{E}-03$ & & \\
\hline 25 & 0.5 & 37.531 & 141.446 & 33.369 & 582 & 13.9 & 595 & 10.3 & 1.0 & 0.85 & $4.93 \mathrm{E}-03$ & 36 & 11.0 \\
\hline 25 & 10 & 37.520 & 141.446 & 34.032 & 193 & 4.7 & 200 & 3.7 & 1.0 & 0.85 & 7.09E-03 & & \\
\hline 25 & 20 & 37.520 & 141.446 & 34.280 & 202 & 6.6 & 216 & 6.2 & 0.9 & 0.49 & $3.91 \mathrm{E}-03$ & & \\
\hline 25 & 50 & 37.520 & 141.446 & 33.931 & 117 & 2.5 & 125 & 1.7 & 0.9 & 0.71 & $3.23 \mathrm{E}-03$ & & \\
\hline 25 & 90 & 37.520 & 141.446 & 33.810 & 76.4 & 2.1 & 74.5 & 1.7 & 1.0 & 1.74 & $1.27 \mathrm{E}-03$ & & \\
\hline 26 & 0.5 & 36.998 & 141.400 & 33.949 & 460 & 11.0 & 465 & 8.2 & 1.0 & 0.33 & $1.06 \mathrm{E}-02$ & 26 & 4.3 \\
\hline 27 & 0.5 & 36.497 & 141.398 & 33.949 & 717 & 19.5 & 753 & 16.7 & 1.0 & 0.37 & & & \\
\hline 27 & 10 & 36.497 & 141.398 & 34.092 & 499 & 10.7 & 518 & 6.7 & 1.0 & 0.37 & $1.27 \mathrm{E}-03$ & & \\
\hline 27 & 20 & 36.497 & 141.398 & 34.141 & 425 & 11.1 & 415 & 8.8 & 1.0 & 0.31 & $4.25 \mathrm{E}-03$ & & \\
\hline 27 & 50 & 36.497 & 141.398 & 34.124 & 290 & 6.7 & 294 & 4.8 & 1.0 & 0.32 & $6.05 \mathrm{E}-03$ & & \\
\hline 27 & 100 & 36.497 & 141.398 & 34.208 & 35.8 & 1.2 & 34.0 & 1.1 & 1.1 & & & & \\
\hline 28 & 0.5 & 36.006 & 141.399 & 33.983 & 7.9 & 0.6 & 6.5 & 0.6 & 1.2 & 0.34 & $2.49 \mathrm{E}-03$ & & 11.2 \\
\hline 29 & 0.5 & 36.498 & 142.010 & 33.254 & 3477 & 70.3 & 3565 & 37.3 & 1.0 & 0.84 & $7.66 \mathrm{E}-03$ & 29 & 17.6 \\
\hline 29 & 10 & 35.996 & 144.006 & 34.022 & 391 & 8.0 & 390 & 4.7 & 1.0 & 0.36 & & & \\
\hline 29 & 20 & 35.996 & 144.006 & 34.282 & 314 & 7.2 & 333 & 5.2 & 0.9 & 0.31 & $3.67 \mathrm{E}-03$ & & \\
\hline 29 & 50 & 35.996 & 144.006 & 34.370 & 113 & 2.5 & 117 & 1.7 & 1.0 & 0.22 & $2.78 \mathrm{E}-03$ & & \\
\hline 29 & 100 & 35.996 & 144.006 & 34.193 & 30.9 & 1.2 & 29.2 & 1.2 & 1.1 & 0.40 & $8.73 \mathrm{E}-03$ & & \\
\hline 30 & 0.5 & 36.496 & 142.495 & 33.927 & 720 & 17.5 & 738 & 13.3 & 1.0 & 0.37 & $3.01 \mathrm{E}-03$ & 46 & 20.6 \\
\hline 31 & 0.5 & 36.999 & 142.500 & 33.899 & 440 & 11.0 & 453 & 8.7 & 1.0 & 0.34 & $6.82 \mathrm{E}-03$ & 33 & 27.5 \\
\hline 32 & 0.5 & 36.998 & 142.001 & 34.065 & 327 & 7.7 & 332 & 5.7 & 1.0 & 0.28 & $6.61 \mathrm{E}-04$ & & \\
\hline
\end{tabular}




\section{Results}

The June 2011 cruise track was confined mainly to the north of the Kuroshio Current, with the majority of stations concentrated within an inshore "box" as defined in Buesseler et al. (2012) (Fig. 1). The Kuroshio acted as a barrier to southward Cs transport, as evidenced by the low to non-detectible levels of ${ }^{134} \mathrm{Cs}$ in stations within and to the south of the current. We will use mainly ${ }^{134} \mathrm{Cs}$ in figures and data interpretation since, unlike ${ }^{137} \mathrm{Cs}$, this isotope no longer has a background inventory in the ocean from nuclear weapons testing due to its relatively short half life. Hence, its distribution is controlled entirely by discharged coolant waters and atmospheric inputs from the Fukushima NPP. Furthermore, for most stations north of the Kuroshio, the ${ }^{137} \mathrm{Cs}:{ }^{134} \mathrm{Cs}$ activity ratio $(\sim 1)$ was equivalent to the known value for FNPP discharges to the ocean (Buesseler et al., 2011) such that the spatial distribution and inventory of the two isotopes were roughly the same within our study region. Therefore, fluxes and inventories of ${ }^{137} \mathrm{Cs}$ are, within uncertainty, the same as those calculated here for ${ }^{134} \mathrm{Cs}$.

Surface samples within the inshore box had the highest Cs isotope activities, ranging from $244-4580 \mathrm{~Bq} \mathrm{~m}^{-3}$ (Fig. 2b, Tables 1 and 2). The outer box stations had a significantly lower ${ }^{134} \mathrm{Cs}$ activity range $\left(<2-333 \mathrm{~Bq} \mathrm{~m}^{-3}\right)$, while stations within the core and to the south of the Kuroshio generally had ${ }^{134} \mathrm{Cs}$ activities at or below the detection limit of the method and ${ }^{137} \mathrm{Cs}$ levels (not shown) equivalent to the known background values for this region $\left(1-2 \mathrm{~Bq} \mathrm{~m}^{-3}\right)$ from past weapons testing fallout (Aoyama and Hirose, 2004). The highest ${ }^{134} \mathrm{Cs}$ and ${ }^{137} \mathrm{Cs}$ activities $\left(3570-4580 \mathrm{~Bq} \mathrm{~m}^{-3}\right)$ were associated with an eddy at station 29 (Fig. 1b; Rypina et al., 2013). The signature of this robust cyclonic eddy is clearly visible in AVISO altimetry-based sea surface heights and in trajectories of real and simulated drifters. Although this feature was not completely stationary, the range of its motion was limited and it stayed in the area from April to July.

The highest ${ }^{228} \mathrm{Ra} /{ }^{226} \mathrm{Ra}$ activity ratios $(0.75-0.85)$ were found at stations within the inshore box, coincident with the highest $\mathrm{Cs}$ isotope activities and consistent with water masses with a largely coastal signature (Fig. 2a, Tables 1 and 2) (Yamada and Nozaki, 1986; Inoue et al., 2007, 2010). The short-lived Ra isotope distributions are reported in the discussion section in the context of a Ra-based model for calculating water mass age. While ${ }^{228} \mathrm{Ra} /{ }^{226} \mathrm{Ra}$ is expected to decrease with distance from shore when cross-shelf mixing is dominated by diffusion, we found many exceptions to this rule, suggesting that offshore transport was impacted by advection in some areas (Fig. 1b). The eddy station was a particularly clear example, with an Ra isotopic signature that was higher than most near shore stations, which suggests that this station contained a significant fraction of relatively undiluted coastal seawater, consistent with the similarly high Cs values at these stations.
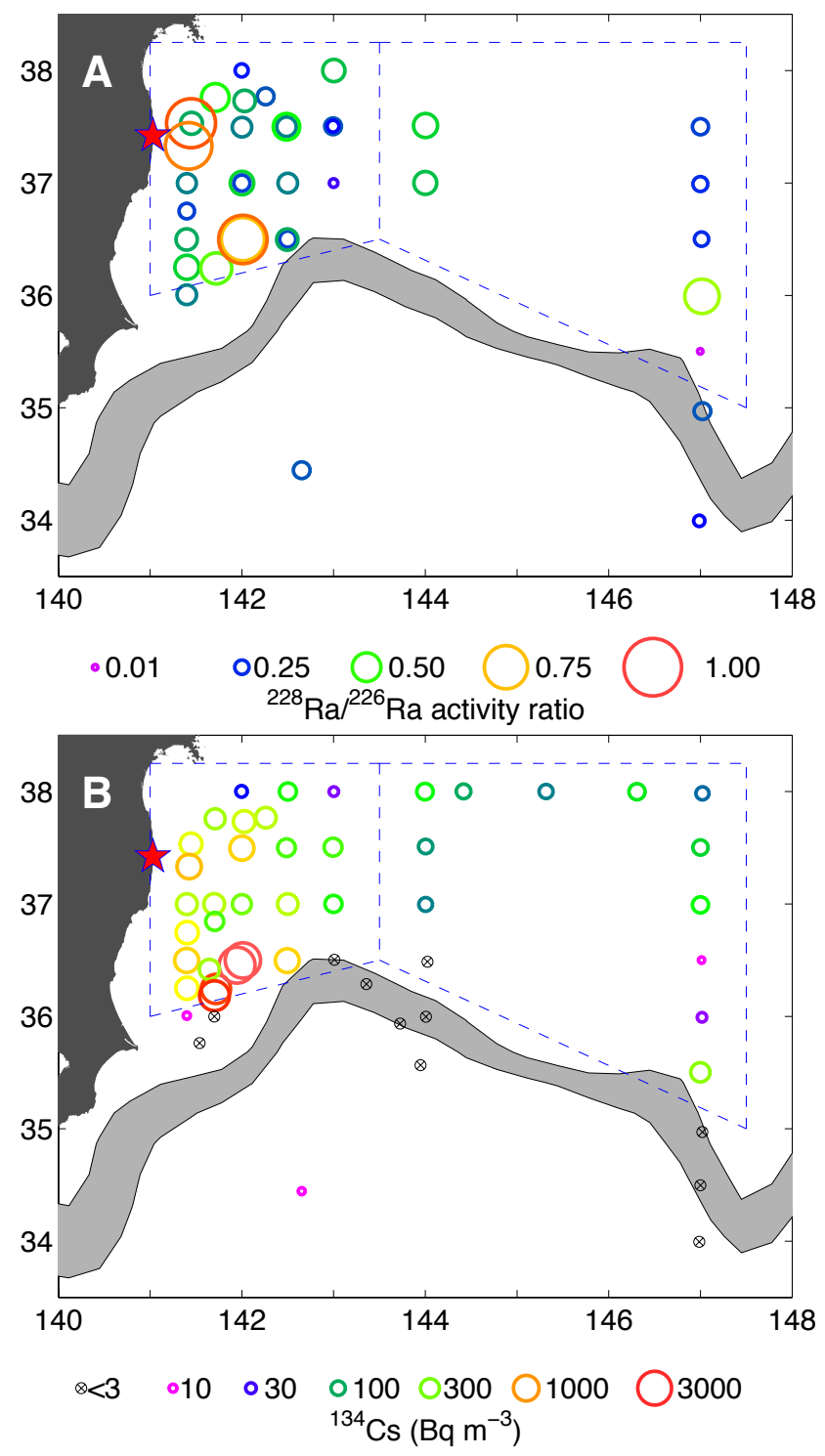

Fig. 2. (A) ${ }^{228} \mathrm{Ra} /{ }^{226} \mathrm{Ra}$ at surface stations. (B) Activities of ${ }^{134} \mathrm{Cs}$ $\left(\mathrm{Bq} \mathrm{m}^{-3}\right)$ at surface stations (from Buesseler et al., 2012). The gray shaded area is the approximate position of the Kuroshio Current during the cruise. Dashed lines delineate the nearshore and offshore study areas; the Cs flux calculations herein focus on the nearshore zone $\left(50000 \mathrm{~km}^{2}\right)$.

\section{Discussion}

Water with high ${ }^{134} \mathrm{Cs}$ tended to have the highest ${ }^{228} \mathrm{Ra} /{ }^{226} \mathrm{Ra}$ activity ratios, indicating that much of the ocean dischargederived ${ }^{137} \mathrm{Cs}$ remained within the coastal zone at the time of our cruise (Fig. 3). The one exception was at stations associated with the eddy, which was pulling in contaminated coastal water from the vicinity of the FNPP and wrapping it cyclonically around the outside of itself. This mechanism produced a build-up of $\mathrm{Cs}$ and ${ }^{228} \mathrm{Ra} /{ }^{226} \mathrm{Ra}$ near the perimeter of the eddy, but left the eddy core relatively free of 


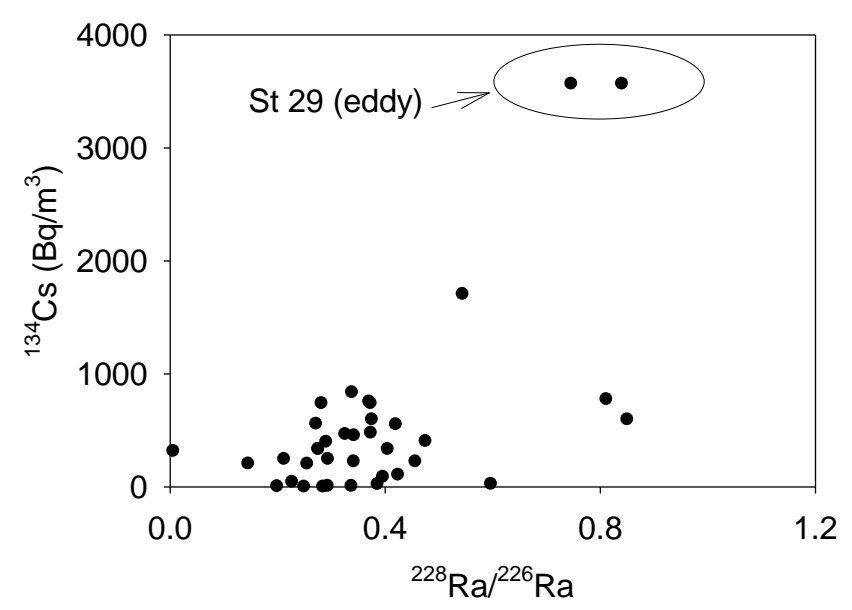

Fig. 3. The relationship between the ${ }^{228} \mathrm{Ra} / 226 \mathrm{Ra}$ activity ratio and ${ }^{134} \mathrm{Cs}\left(\mathrm{Bq} \mathrm{m}^{-3}\right)$. Note the highest ${ }^{134} \mathrm{Cs}$ in eddy at station 29 also has a high ${ }^{228} \mathrm{Ra}^{/ 226} \mathrm{Ra}$, suggesting that the water in this eddy came from the cooling of the reactors with Ra-rich coastal water.

coastal-derived constituents. The larger tracer activities near the perimeter and smaller values near the center are typical for tracer distributions when the tracer source is located outside of an eddy (e.g. Rypina et al., 2013).

While the ${ }^{228} \mathrm{Ra} /{ }^{226} \mathrm{Ra}$ ratios allow us to make a qualitative connection regarding $\mathrm{Cs}$ isotope provenance within the study region, they cannot be used to assign a precise age to the water masses within the study region. To calculate water mass ages, equivalent to the replacement time $\left(T_{\mathrm{r}}\right)$ of water in the study area, we need to employ one of the short-lived $\mathrm{Ra}$ isotopes for which the following model can be applied (Moore, 2000; Charette et al., 2001):

$$
\underbrace{\left[\frac{{ }^{223} \mathrm{Ra}_{\mathrm{ex}}}{{ }^{228} \mathrm{Ra}_{\mathrm{ex}}}\right]_{\mathrm{obs}}}_{A}=\underbrace{\left[\frac{{ }^{223} \mathrm{Ra}_{\mathrm{ex}}}{{ }^{228} \mathrm{Ra}_{\mathrm{ex}}}\right]_{i}}_{B} e^{-\lambda_{223} T_{\mathrm{r}}},
$$

where $A$ is the activity ratio at the individual stations, $B$ is the activity ratio being supplied from sediment-water interaction along the coast, and $\lambda_{223}$ is the decay constant for ${ }^{223} \mathrm{Ra}$. This method is based on the relative decay rates of the two isotopes as they mix away from the source (defined here as the shoreline), and upon the assumption that the initial activity ratio is constant. For the latter assumption, we do not have measurements of ${ }^{223} \mathrm{Ra}$ in this exact study region so we used the crustal average ratio for ${ }^{223} \mathrm{Ra} /{ }^{228} \mathrm{Ra}$ (0.05; Rama and Moore, 1996). By normalizing the shortlived ${ }^{223} \mathrm{Ra}$ to the long-lived ${ }^{228} \mathrm{Ra}$, artifacts due to mixing are removed. The model also assumes that the open ocean contains negligible activities of the two Ra isotopes. In the case of ${ }^{223} \mathrm{Ra}$, we use ${ }^{223} \mathrm{Ra}_{\mathrm{ex}}$, which is ${ }^{223} \mathrm{Ra}$ not supported by ${ }^{227} \mathrm{Ac}$ in the water column and is typically well below detection in the open ocean. In contrast, ${ }^{228} \mathrm{Ra}$ is generally unsupported in the water column by its parent isotope

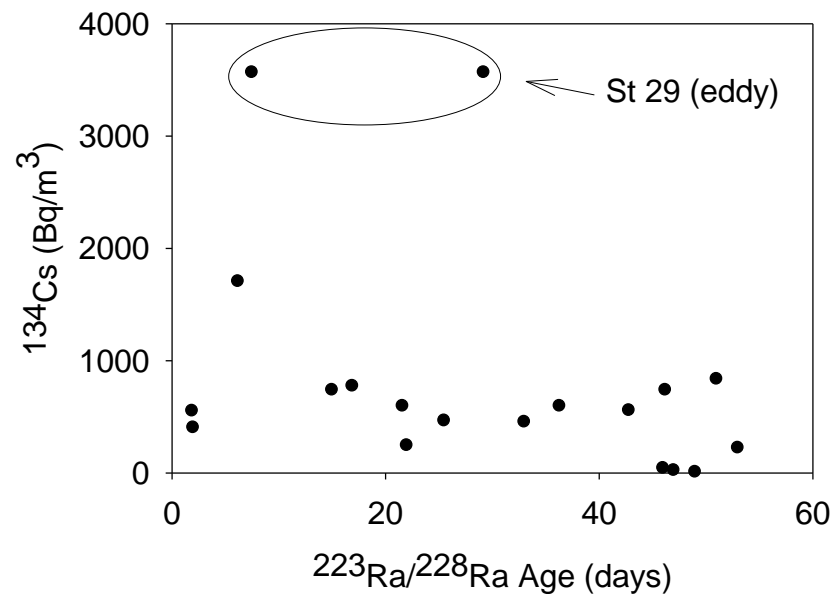

Fig. 4. Radium-derived water mass age (days) versus ${ }^{134} \mathrm{Cs}$ $\left(\mathrm{Bq} \mathrm{m}^{-3}\right)$.

$\left({ }^{232} \mathrm{Th}\right)$, such that typical minimum values in the Pacific Ocean are ${ }^{228} \mathrm{Ra}=0.5 \mathrm{dpm} 100 \mathrm{~L}^{-1}$ (Huh and $\mathrm{Ku}, 1998$ ). Hence, ${ }^{228} \mathrm{Ra}_{\mathrm{ex}}$ is defined as ${ }^{228} \mathrm{Ra}$ corrected for this open ocean background value. For the in situ pump surface samples, where we do not know the absolute ${ }^{228}$ Ra activity, the background value was adjusted to account for the less than quantitative Ra recovery of the cartridges by assuming that the ${ }^{226} \mathrm{Ra}$ activity in all samples was $8 \mathrm{dpm} 100 \mathrm{~L}^{-1}$.

Given the 11.4 day half life of ${ }^{223} \mathrm{Ra}$, this method is useful for water mass age dating up to $\sim 2$ months. In the case of ${ }^{224} \mathrm{Ra}$, while the same model framework described above can be theoretically applied, its relatively short half-life of 3.66 days did not allow us to fully constrain ages for as many stations as we were able to do with ${ }^{223} \mathrm{Ra}$.

Radium water mass ages estimated from the surface water samples using the above analytical expression are shown in Fig. 4 relative to the ${ }^{134} \mathrm{Cs}$ distribution. For the stations where the model age could be estimated, ages ranged from a few days up to $>50$ days. Given the overall low activities, the uncertainties on the Ra ages averaged $46 \%$ (though significantly lower for younger ages). Unlike ${ }^{228} \mathrm{Ra} /{ }^{226} \mathrm{Ra}$, which due to the longer ${ }^{228} \mathrm{Ra}$ half-life will retain its coastal signature for a significantly longer period of time, there was not a significant correlation between ${ }^{223} \mathrm{Ra} /{ }^{228} \mathrm{Ra}$ age and ${ }^{134} \mathrm{Cs}$ activity. This is not entirely unexpected given that the vast majority of the FNPP release took place in late March/early April 2011. Hence, despite spending more time in the ocean and being more diluted, older coolant waters from the FNPP often had higher Cs concentrations than more recent and less Cs-rich younger waters. This is consistent with the model results of Rypina et al. (2013). The estimated average water mass age for stations within the inshore box was 32 days.

We compared the Ra-derived ages with an independent estimate of the water age from an oceanographic numerical model. Briefly, large numbers of simulated water parcels are released at positions and times corresponding to each station, 


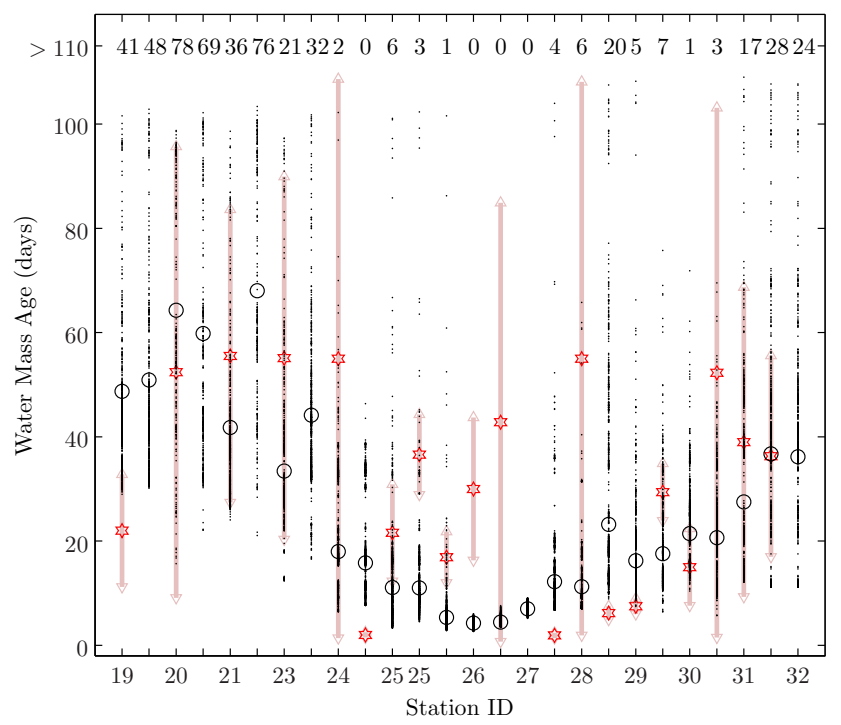

Fig. 5. Ra-based (red) and oceanographic-model-based (black) water mass age at each station. The mean Ra-based age is shown by red stars; pink line segments show the Ra age standard deviation. The mean model-based water age is indicated by black circles, while the ages of individual water parcels (an indication of the range of values) are shown as small black dots. The percentage of water parcels with model-based ages $>110$ days is indicated near the top of the plot for each station.

with trajectories of these water parcels followed backward in time until they reach the coast. In our simulations, we released 100 parcels within a $5 \times 5 \mathrm{~km}$ domain centered at each station, every half hour during $6 \mathrm{~h}$, which corresponds to the average water sampling duration at each station. The velocity field used to advect water parcels was inferred from AVISO altimetry and NCEP/NCAR reanalysis wind stresses, with a small stochastic velocity added to account for the lateral diffusion and the influence of the unresolved scales. More details on the model can be found in Rypina et al. (2013).

A station-by-station comparison between the Ra-based and numerically simulated water ages is presented in Fig. 5. For most stations, the Ra age (within error) overlaps with the average oceanographic model age or significant number of the simulated water parcel ages. In general, water age decreases from offshore to inshore for both methods, though the Ra-derived ages are systematically higher. This is reflected in the mean oceanographic water age averaged over all the nearshore stations of 27 days, compared with the Ra-based age average of 32 days. While on average the two methods agree quite well, our higher value could be a result of an overestimate of the initial ${ }^{223} \mathrm{Ra} /{ }^{228} \mathrm{Ra}$ ratio used in our model. For example, a ${ }^{223} \mathrm{Ra} /{ }^{228} \mathrm{Ra}$ ratio of 0.04 (vs. 0.05) would bring our average value in line with the oceanographic model estimate.

Buesseler et al. (2012) quantified a ${ }^{134} \mathrm{Cs}$ inventory of $26000 \mathrm{~Bq} \mathrm{~m}^{-2}$ for the surface mixed layer of the inshore box. This translates to $1.25 \mathrm{PBq}$ for the $50000 \mathrm{~km}^{2}$ inshore area and an offshore horizontal flux at the time of the cruise of $3.9 \times 10^{13} \mathrm{Bqd}^{-1}$, using the average Ra age (32 d) or $4.6 \times 10^{13} \mathrm{~Bq} \mathrm{~d}^{-1}$ with the numerical model age $(27 \mathrm{~d})$.

Water column stratification will tend to constrain the majority of the Fukushima NPP release products within the upper ocean within the first few months after the initial release. However, $\mathrm{Ra}$ isotopes allow us to quantify the vertical $\mathrm{Cs}$ flux due to diapycnal mixing at the time of our cruise. Vertical dispersion of a radium isotope (or any other conservative tracer) in the ocean can typically be approximated as a diffusive (rather than advective) process. For such a case, a simple one-dimensional diffusion model can be written as

$$
\frac{\mathrm{d} A}{\mathrm{~d} t}=K_{z} \frac{\partial^{2} A}{\partial z^{2}}-\lambda A,
$$

where $A$ is the radium isotope activity, $K_{z}$ is the vertical eddy diffusion coefficient, $z$ is the depth, and is the decay constant for the isotope of interest. At steady state, this equation can be rearranged as

$A_{z}=A_{0} \cdot \exp \left[-z \sqrt{\frac{\lambda}{K_{z}}}\right]$,

where $A_{z}$ is the activity at depth $z$ relative to the ocean surface and $A_{0}$ is the radium activity at the surface $(z=0)$. Given that diapycnal mixing is a significantly slower process than upper ocean horizontal mixing, the longer-lived ${ }^{228} \mathrm{Ra}$ must be used to evaluate mixing across the thermocline. Here we use the ${ }^{228} \mathrm{Ra} /{ }^{226} \mathrm{Ra}$ ratio instead of ${ }^{228} \mathrm{Ra}$ alone, since profile samples were collected with the cartridge method where Ra recovery was not $100 \%$. In this case, $K_{z}$ can be calculated from slope $(s)$ of a plot of $\ln \left({ }^{228} \mathrm{Ra} /{ }^{226} \mathrm{Ra}\right)$ vs. depth $\left(K_{z}=\lambda / s^{2}\right)$. The model assumes a constant, steadystate source of ${ }^{228} \mathrm{Ra}$ in the surface mixed layer and does not take into account lateral input of ${ }^{228} \mathrm{Ra}$ below the surface mixed layer (Charette et al., 2007).

We applied this tracer-based model of vertical exchange to ${ }^{228} \mathrm{Ra} /{ }^{226} \mathrm{Ra}$ data from station 21 (Fig. 6). This station was chosen because it was the only one outside the influence of the eddy feature and far enough from shore such that subsurface horizontal exchange would be minimal. Here, we observed an exponential decrease of both ${ }^{228} \mathrm{Ra} /{ }^{226} \mathrm{Ra}$ and ${ }^{134} \mathrm{Cs}$ across the thermocline. The ${ }^{228} \mathrm{Ra} /{ }^{226} \mathrm{Ra}$ activity ratio decreased from 0.46 at the surface to 0.08 at $100 \mathrm{~m}$, while ${ }^{134} \mathrm{Cs}$ decreased from 223 to $47 \mathrm{~Bq} \mathrm{~m}^{-3}$ across the same depth range. Slightly higher ${ }^{134} \mathrm{Cs}$ and ${ }^{228} \mathrm{Ra} /{ }^{226} \mathrm{Ra}$ just below the mixed layer at $35 \mathrm{~m}$ may be the remnants of a slightly older, coastal seawater-rich water mass. The ${ }^{228} \mathrm{Ra} /{ }^{226} \mathrm{Ra}$ data best fits a $K_{z}$ of $0.7 \mathrm{~m}^{2} \mathrm{~d}^{-1}\left(0.1 \mathrm{~cm}^{2} \mathrm{~s}{ }^{-1}\right)$, which agrees fairly well with the available direct measurements of the open-ocean vertical diffusivity (Ledwell et al., 1998; Law et al., 2003). Note also that our estimate may be slightly overestimated if there is a subsurface input of ${ }^{228} \mathrm{Ra}$ from the shelf area flowing along the isopycnals. 


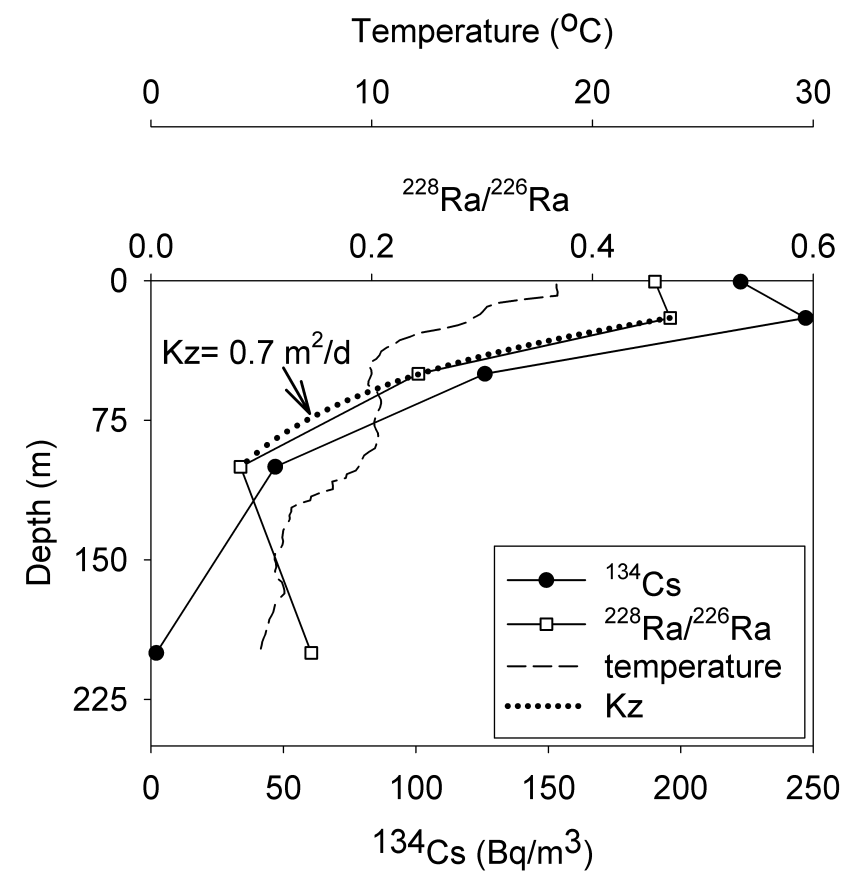

Fig. 6. The upper ocean distribution of ${ }^{228} \mathrm{Ra} /{ }^{226} \mathrm{Ra}$ and ${ }^{134} \mathrm{Cs}$ at station 21 . The vertical gradient in ${ }^{228} \mathrm{Ra} / 226 \mathrm{Ra}$ was used to derive the eddy diffusivity $\left(K_{z}\right)$ and ultimately the transport of Cs across the thermocline within the study domain.

Combined with the ${ }^{134} \mathrm{Cs}$ within the inshore study region $\left(26000 \mathrm{~Bq} \mathrm{~m}^{-2}\right)$ and assuming relatively constant vertical mixing rates across the study domain, we estimate a vertical ${ }^{134} \mathrm{Cs}$ flux of $1.8 \times 10^{4} \mathrm{~Bq} \mathrm{~d}^{-1}$. Hence, for June 2011, horizontal mixing dispersed Fukushima NPP Cs at a rate $\sim 10^{9}$ times faster than vertical mixing. This is consistent with the Buesseler et al. (2012) observation that roughly $90 \%$ of the ${ }^{134} \mathrm{Cs}$ isotope inventory was restricted to the surface mixed layer.

Considerable controversy remains as to the total amount of Cs (and other fuel and/or fission products) released from the Fukushima NPP accident (Buesseler et al., 2012; Bailly du Bois et al., 2012; Tsumune et al., 2011). Given that Fukushima Cs at the time of our cruise was mostly contained within the surface mixed layer, we constructed a simple mixing model designed to estimate the total Cs released from the site through direct discharge to the ocean:

$I_{t}=\frac{I_{i}}{e^{-k t}}$,

where $I_{t}$ is the Cs inventory at time $(t)$ before the June 2011 cruise, $I_{i}$ is the Cs inventory at the time of the cruise, and $k$ is the rate constant for $\mathrm{Cs}$ removal from the study area. In this case, $k$ is equal to $1 / T_{\mathrm{r}}$, the Ra-derived water mass age.

This "hindcast" model has several key assumptions. First and foremost, we assume that the majority of the ocean discharge occurred within a few days in early April 2011. This assumption is supported by the record of Cs activities over

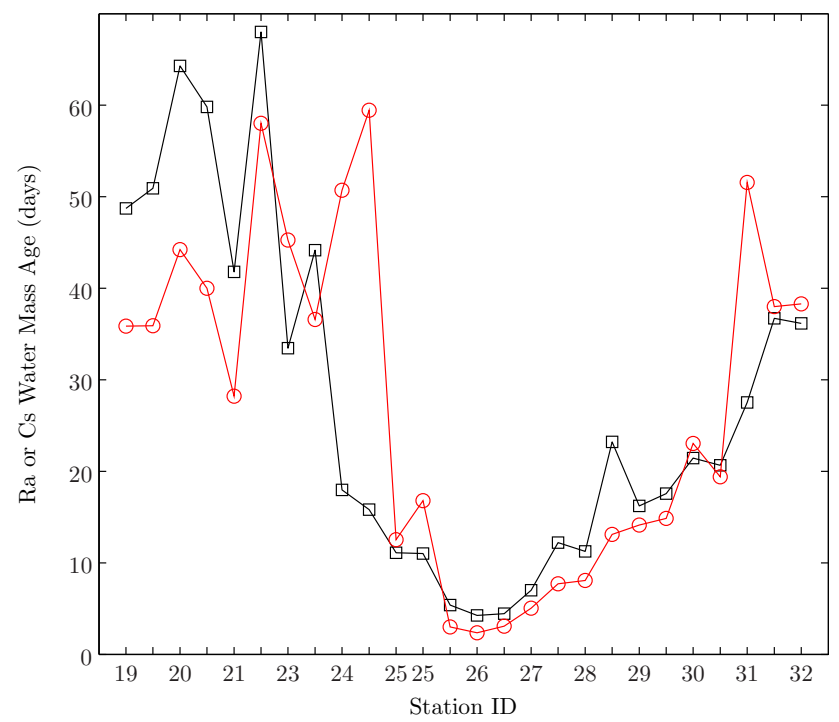

Fig. 7. Radium water mass age (black) and oceanographic-modelbased water Cs age (black) at each station. The Cs age is defined as the transit time from the Fukushima NPP to the station of interest at the time of each station occupation during the cruise.

time at the Fukushima NPP discharge channels, which indicated peak values on 6 April and significantly lower values both before and after this time (Buesseler et al., 2011). Second, the model requires that the Ra-based water ages within our study area remained constant between April and the time of our cruise. This is a reasonable assumption given that there were no major storms or other extreme events during that time period that would qualitatively change the character of the lateral motion of fluid in the area. Third, we assume that the Ra age and the Cs age are roughly equivalent. Conceptually, this assumption may not be satisfied since directly discharged Cs was a point source, while the Ra source is the entire coastline. However, the oceanographic numerical model also suggests a good correlation (Fig. 7) between the Ra-based water age (time since the water parcel left the coast) and Cs age (time since the parcel left the Fukushima NPP computed from the Rypina et al., 2013 model). Lastly, in order for the model to be strictly an estimate of the ocean discharge-derived Cs, we must assume that no atmospherically sourced Cs was present within our study area at the time of the cruise. This generally agrees with the results reported in Rypina et al. (2013) and is supported by the excellent correlation between $\mathrm{Cs}$ isotopes and ${ }^{90} \mathrm{Sr}$, with the latter being a non-volatile fission product and therefore could only have been sourced from direct discharge and not atmospheric fallout (Casacuberta et al., 2013).

Using an average Ra age of 32 days and a June 2011 ${ }^{134} \mathrm{Cs}$ inventory $\left(I_{i}\right)$ of $1.25 \mathrm{PBq}$, our mixing model suggests that $11 \mathrm{PBq}$ of ${ }^{134} \mathrm{Cs}$ (and ${ }^{137} \mathrm{Cs}$, assuming an activity ratio of $\sim 1$ ) was released to the ocean through direct discharge at the time of peak release in early April 2011. Using the 
numerical-model-based average age of 27 days, this value increases to $16 \mathrm{PBq}$. Our direct discharge estimated range is significantly greater $(\sim 2-5$ times $)$ than an early $(3.5 \mathrm{PBq}$, Tsunume et al., 2011) and more recent estimate of direct ocean release (5.1-5.5 PBq, Estournel et al., 2012), but generally consistent with the estimate $(16.2 \pm 1.6 \mathrm{PBq})$ obtained by Rypina et al. (2013), and within the range of 12-41 PBq reported by Bailly du Bois et al. (2012). The variability in total direct ocean discharges of $\mathrm{Cs}$ is due to the large uncertainties of the different transport and inversion processes used by each study and lack of spatially distributed observations in the surrounding region, which leads to uncertainty in the ocean inventory of $\mathrm{Cs}$ at any given point in time.

\section{Conclusions}

We have provided key estimates of Cs isotope dispersion away from the Fukushima NPP through horizontal and vertical-mixing processes constrained by radium isotopes. A "hindcast" mixing model was constructed in order to provide an independent estimate of the direct ocean discharge of Cs isotopes to the Pacific Ocean. Continued leakage of radionuclides into the ocean at the time of our cruise, and continued leakage at the time this article was written make this $11-16 \mathrm{PBq}$ source term for both ${ }^{134} \mathrm{Cs}$ and ${ }^{137} \mathrm{Cs}$ a lower limit value.

At present, significant uncertainties remain as to the exact pathway that Cs took (and will take in the future) from the reactors to the sea. Though most of the atmospheric fallout was believed to be over the ocean (Yoshida and Kanda, 2012), fallout over land presumably led to Cs enrichment in river runoff and potential contamination of surficial aquifers. From column experiments using ion exchange media and local soils, Ohta et al. (2012) found that the ${ }^{137}$ Cs migration rate was only $0.6 \mathrm{~mm} \mathrm{yr}^{-1}$, suggesting that rain-derived Fukishima Cs will not likely lead to contamination of the local aquifers in the near term. At the FNPP site, however, cracks in reactor foundations combined with potentially inefficient methods for collecting cooling water most certainly led to direct radionuclide inputs to the local aquifer with the potential for transport to the coastal ocean via submarine groundwater discharge (SGD) (Taniguchi, 2002). Since cesium's affinity for particle surfaces decreases with increasing ionic strength (Rani and Sasidhar, 2012), seawater intrusion driven by tidal pumping or seasonal changes in the hydraulic gradient may serve to mobilize aquifer sediment-bound Cs, thereby increasing the SGD-derived Cs flux to the ocean. This subsurface pathway, both at the Fukushima NPP and in the wider fallout region, is completely unconstrained at present and requires further study, not only for Cs but also for other reactor sources such as ${ }^{90} \mathrm{Sr}$, which is much more mobile than Cs in groundwater (Wallace et al., 2012). Radium isotopes, which have been proven useful for quantifying SGD and associated trace element and nutrient fluxes (Charette et al., 2008), may play a role in resolving this issue, which may represent a legacy source of Cs isotopes and other radionuclides to the ocean long after the reactor clean up process has been completed.

Acknowledgements. The authors thank the Gordon and Betty Moore Foundation for funding this effort as well as the captain and crew of the R/V Ka'imikai-O-Kanoloa for their assistance in collecting the samples. We thank Henrieta Dulaiova for help with cruise preparation relating to the on board radium measurements.

Edited by: M. Dai

\section{References}

Aoyama, M. and Hirose, K.: Artificial radionuclides database in the Pacific Ocean: HAM database, Scientific World Journal, 4, 200215, 2004.

Bailly du Bois, P., Laguionie, P., Boust, D., Korsakissok, I., and Didier, D: Estimation of marine source-term following Fukushima Dai-ichi accident, J. Environ. Radioactiv., 114, 2-9, 2012.

Broecker, W. S., and Peng, T. H.: Tracers in the Sea, Eldigio Press Lamont Doherty Geological Observatory, 690 pp., 1982.

Buesseler, K. O., Casso, S. A., Hartman, M. C., and Livingston, H. D.: Determination of fission-products and actinides in the Black Sea following the Chernobyl accident, J. Radioanal. Nucl. Ch., 138, 33-47, 1990.

Buesseler, K. O., Aoyama, M., and Fukasawa, M: Impacts of the Fukushima nuclear power plants on marine radioactivity, Environ. Sci. Technol., 45, 9931-9935, 2011.

Buesseler, K. O., Jayne, S. R., Fisher, N. S., Rypina, I. I., Baumann, H., Baumann, Z., Breier, C. F., Douglass, E. M., George, J., Macdonald, A. M., Miyamoto, H., Nishikawa, J., Pike, S. M., and Yoshida, S: Fukushima-derived radionuclides in the ocean and biota off Japan, P. Natl. Acad. Sci. USA, 109, 5984-5988, 2012.

Casacuberta, N., Masqué, P., Garcia-Orellana, J., Garcia-Tenorio, R., and Buesseler, K. O.: ${ }^{90} \mathrm{Sr}$ and ${ }^{89} \mathrm{Sr}$ in seawater off Japan as a consequence of the Fukushima Dai-ichi nuclear accident, Biogeosciences Discuss., 10, 2039-2067, doi:10.5194/bgd-10-20392013, 2013.

Charette, M. A., Buesseler, K. O., and Andrews, J. E.: Utility of radium isotopes for evaluating the input and transport of groundwater-derived nitrogen to a Cape Cod estuary, Limnol. Oceanogr., 46, 465-470, 2001.

Charette, M. A., Gonneea, M. E., Morris, P. , Statham, P., Fones, G., Planquette, H. I., and Salter, A.: Naveira Garabato, Salter and A. N. Garabato (2007) Radium isotopes as tracers of iron sources fueling a Southern Ocean phytoplankton bloom, Deep-Sea Res. II, 54, 1989-1998, 2007.

Charette, M. A., Moore, W. S., and Burnett, W. C.: Uranium- and thorium-series nuclides as tracers of submarine groundwater discharge, in: U-Th Series Nuclides in Aquatic Systems, edited by: Krishnaswami S. and Cochran, J. K., Volume 13 in Series: Radioactivity in the Environment, Elsevier, 155-192, 2008.

Chino, M., Nakayama, H., Nagai, H., Terada, H., Katata, G., and Yamazawa, H.: Preliminary estimation of release amounts of ${ }^{131} \mathrm{I}$ and ${ }^{137} \mathrm{Cs}$ accidentally discharged from the Fukushima Daiichi 
Nuclear Power Plant into the atmosphere, J. Nucl. Sci. Technol., 48, 1129-1134, 2011.

Dulaiova, H., Henderson, P., Ardelan, M. V., and Charette, M. A.: Global Biogeochem. Cy., 23, GB4014, doi:10.1029/2008GB003406, 2009.

Estournel, C., Bosc, E., Bocquet, M., Ulses, C., Marsaleix, P., Winiarek, V., Osvath, I., Nguyen, C., Duhaut, T., Lyard, F., Michaud, H., and Auclair, F.: Assessment of the amount of cesium-137 released into the Pacific Ocean after the Fukushima accident and analysis of its dispersion in Japanese coastal waters, J. Geophys. Res., 117, C11014, doi:10.1029/2012JC007933, 2012.

Henderson, P. B., Morris, P. J., Moore, W. S., and Charette, M. A.: Methodological advances for measuring low-level radium isotopes in seawater, J. Radioanal. Nucl. Ch., 293, 1-6, doi:10.1007/s10967-012-2047-9, 2012.

Huh, C. A. and Ku, T. L: A 2-D section of ${ }^{228} \mathrm{Ra}$ and ${ }^{226} \mathrm{Ra}$ in the Northeast Pacific, Oceanol. Acta, 21, 533-542, 1998.

Inoue, M., Tanaka, K., Kofuji, H., Nakano, Y., and Komura, K: Seasonal variation in the ${ }^{228} \mathrm{Ra} /{ }^{226} \mathrm{Ra}$ ratio of coastal water within the Sea of Japan: Implications for the origin and circulation patterns of the Tsushima Coastal Branch Current, Mar. Chem., 107, 559-568, 2007.

Inoue, M., Nakano, Y., Kiyomoto, Y., Kofuji, H., Hamajima, Y., and Yamamoto, M: Seasonal variation in the ${ }^{228} \mathrm{Ra} /{ }^{226} \mathrm{Ra}$ ratio in surface water from the East China Sea and the Tsushima Strait, J. Oceanogr., 66, 425-428, 2010.

Krest, J. M., Moore, W. S., Gardner, L. R. and Morris, J. T: Marsh nutrient export supplied by groundwater discharge: Evidence from radium measurements, Global Biogeochem. Cy., 14, 167176, doi:10.1029/1999GB001197, 2000.

Law, C. S., Abraham, E. R., Watson, A. J., and Liddicoat, M. I.: Vertical eddy diffusion and nutrient supply to the surface mixed layer of the Antarctic Circumpolar Current, J. Geophys. Res., 108, 3272, doi:10.1029/2002JC001604, 2003.

Ledwell, J. R., Watson, A. J., and Law, C. S: Mixing of a tracer in the pycnocline, J. Geophys. Res., 103, 21499-21529, 1998.

Moore, W. S.: Ages of continental shelf waters determined from ${ }^{223} \mathrm{Ra}$ and ${ }^{224} \mathrm{Ra}$, J. Geophys. Res., 105, 117-122, 2000

Moore, W. S.: Fifteen years experience in measuring $\mathrm{Ra}^{224}$ and $\mathrm{Ra}^{223}$ by delayed-coincidence counting, Mar. Chem., 109, 188197, 2008.
Moore, W. S. and Arnold, R.: Measurement of ${ }^{223} \mathrm{Ra}$ and ${ }^{224} \mathrm{Ra}$ in coastal waters using a delayed coincidence counter, J. Geophys. Res. 101, 1321-1329, 1996.

Ohta, T., Mahara, Y., Kubota, T. Fukutani, S., Fujiwara, K., Takamiya, K., Yoshinaga, H., Mizuochi, H., and Igarashi, T.: Prediction of groundwater contamination with ${ }^{137} \mathrm{Cs}$ and ${ }^{131} \mathrm{I}$ from the Fukushima nuclear accident in the Kanto district, J. Environ. Radioactiv., 111, 38-41, 2012.

Pike, S. M., Buesseler, K. O., Breier, C. B., and Duliaova, H: Quantification of cesium in seawater off Japan using extraction with AMP-PAN resin and quantification via gamma spectroscopy and inductively coupled mass spectrometry, J. Radioanal. Nucl. Ch., 239, doi:10.1007/s10967-012-2014-5, 2012.

Rama and Moore, W. S.: Using the radium quartet for evaluating groundwater input and water exchange in salt marshes, Geochim. Cosmochim. Ac., 60, 4645-4652, 1996.

Rani, R. D. and Sasidhar, P.: sorption of cesium on clay colloids: kinetic and thermodynamic studies, Aquat. Geochem., 18, 281296, 2012.

Rypina, I. I., Jayne, S. R., Yoshida, S., Macdonald, A. M., Douglass, E., and Buesseler, K.: Short-term dispersal of Fukushimaderived radionuclides off Japan: modeling efforts and modeldata intercomparison, Biogeosciences Discuss., 10, 1517-1550, doi:10.5194/bgd-10-1517-2013, 2013.

Taniguchi, M.: Tidal effects on submarine groundwater discharge into the ocean, Geophys. Res. Lett., 29, 1561, doi:10.1029/2002GL014987, 2002.

Tsumune, D., Aoyama, M., Hirose, K., Bryan, F. O., Lindsay, K., and Danabasoglu, G.: Transport of ${ }^{137}$ Cs to the Southern Hemisphere in an ocean general circulation model, Prog. Oceanogr., 89, 38-48, doi:10.1016/j.pocean.2010.12.006, 2011.

Wallace, S. H., Shaw, S., Morris, K., Small, J. S., Fuller, A. J., and Burke, I. T.: ffect of groundwater $\mathrm{pH}$ and ionic strength on strontium sorption in aquifer sediments: Implications for $\mathrm{Sr}-90 \mathrm{mo}-$ bility at contaminated nuclear sites, Appl. Geochem., 27, 14821491, 2012.

Yamada, M. and Nozaki, Y: Radium isotopes in coastal and open ocean surface waters of the Western North Pacific, Mar. Chem. 19379-19389, 1986.

Yoshida, N. and Kanda, J.: Tracking the Fukushima radionuclides, Science, 336, 1115-1116, doi:10.1126/science.1219493, 2012. 